\title{
„JESTEŚMY POŚREDNIKAMI WIARY” (EPISTULA 10 [EXTRA COLL.], 8). WIARA I JEJ POŚREDNICY NA PODSTAWIE LISTÓW ŚW. AMBROŻEGO'
}

Plany Bożej Opatrzności i wiry dziejów postawiły Aureliusza Ambrożego w zadziwiających sytuacjach związanych $\mathrm{z}$ wiarą. Jak sam wyznał, w pewnym momencie dokonało się w jego życiu przejście „od trybunału tego próżnego świata i od wrzawy pochwał publicznych do śpiewu Psalmisty"2. Ambroży z pewnością został wychowany w klimacie wiary. Wśród jego przodków była wszak męczennica imieniem Soteris ${ }^{3}$, a jedyna siostra, Marcellina ${ }^{4}$, jeszcze przed wyborem Ambrożego na biskupa, złożyła w Rzymie ślub dziewictwa w obecności papieża Liberiusza ${ }^{5}$. A jednak on sam pozostawał wciąż katechumenem, chociaż - jak twierdzą badacze ${ }^{6}$ - zaangażowanym w życie wiary i zajmującym się tematyką teologiczną. Również kolejno pełnione funkcje adwokata przy trybunale w Sirmium, namiestnika prowincji Ligurii i Emilii - wymagały od niego zajmowania się sprawami wiary. W pełni - zarówno doktryną jak i życiem wiary - mógł i musiał Ambroży zając się zostawszy biskupem Mediolanu. Już w cztery lata po wyborze zaczął redagować swoje

* Ks. dr Marcin Wysocki - adiunkt w Katedrze Patrologii Greckiej w Instytucie Historii Kościoła i Patrologii na Wydziale Teologii Katolickiego Uniwersytetu Lubelskiego Jana Pawła II; e-mail: mwysocki@kul.lublin.pl.

${ }^{1}$ Jest to druga część dyptyku poświęconego wierze opisywanej przez św. Ambrożego z Mediolanu w jego listach. Część pierwsza dotycząca fenomenu wiary, jej cech i rozwoju została opublikowana w poprzednim tomie „Vox Patrum”: M. Wysocki, ,, Nie ma nic ważniejszego od religii, nic wznioślejszego od wiary” (Ep. 72, 12). Wiara w świetle listów św. Ambrożego, VoxP 60 (2013) 497-511.

${ }^{2}$ Ambrosius, De poenitentia II 8, 72, PL 16, 515: ,[...] sed raptus a tribunalibus, abductus a vanitatibus saeculi huius, a praeconis voce ad psalmistae assuefactus canticum”, thum. W. Szołdrski, w: Św. Ambroży, Wybór pism: O pokucie, O ucieczce od świata, O dobrach przynoszonych przez śmierć, PSP 7, Warszawa 1971, 78.

${ }^{3}$ Prawdopodobnie była ona siostrą babki św. Ambrożego i została ścięta w listopadzie $304 \mathrm{r}$. w czasie prześladowań Dioklecjana. Por. E. Bernasconi, Il nostro sommo padre, Milano 1958, 13; J. Pałucki, Święty Ambroży jako duszpasterz w świetle ekshortacji pastoralnych, Lublin 1996, 18.

${ }^{4}$ Szerzej zob. P. Szczur, Marcelina, EK XI 1226.

${ }^{5}$ Por. Ambrosius, De virginibus 3, 1-14; Pałucki, Święty Ambroży jako duszpasterz, s. 19.

${ }^{6}$ Por. E. Cattanei, La religione a Milano nell'età di Sant'Ambrogio, Milano 1974, 8-9; Pałucki, Święty Ambroży jako duszpasterz, s. 25. 
pierwsze dzieło dogmatyczne - De fide - napisane na prośbę młodego cesarza Gracjana, otoczonego arianami. W dziele tym, które w rzeczywistości nie dotyczy wiary jako takiej, a raczej jest podręcznikiem dogmatyki i wykładem prawd wiary przeciwko arianom, biskup Mediolanu tak pisze we wstępie:

„Wolałbym wprawdzie podjąć się obowiązku zachęcania do wiary niż rozprawiania na jej temat; pierwsze bowiem jest wyrazem nabożnego wyznawania, drugie natomiast pociąga za sobą nierozważną zarozumiałość. Ponieważ jednak ani ty nie potrzebujesz zachęty, ani ja nie mam powodów do wymówienia się tam gdzie chodzi o zbożną powinność, podejmę się ze skromnością śmiałego trudu, by niewiele o wierze rozprawiać, ale przytoczyć na jej prawdziwość wiele świadectw"7.

Wyraźnie więc wskazuje Ambroży, że woli mówić i pisać o wierze jak życiowej postawie, a nie jako o doktrynie. Skoro więc w swym sztandarowym dziele „o wierze" nie podnosi tego zagadnienia, powstaje pytanie: czy jako biskup i nauczyciel wiary pozostawił dzieła w których odnosił się w sposób zwyczajny i prosty do kwestii wiary jako drogi życia? Wydaje się, że takimi pismami powinny być listy, których Ambroży pozostawił ponad 90. One bowiem mają być - przynajmniej w teorii - kontaktem bezpośrednim, wymianą uczuć i myśli. Tak też traktuje swoją korespondencję św. Ambroży. Ona bowiem ,jest żywym odbiciem działalności duszpasterskiej i społecznej biskupa Mediolanu. [...] Nie brak w nich [listach] mądrości i wiary, rzymskiego rozsądku i zdecydowania, ale także serdeczności i ciepła przyjaźni”.

Listy biskupa Ambrożego w kontekście wiary ważne są także z kilku innych powodów. Po pierwsze jest to największy zbiór listów powstały wkrótce po uzyskaniu przez chrześcijaństwo statusu religio licita. Zostały one zatem napisane, i ukazują sytuację chrześcijan i wiary, w nowych warunkach, w nowym wymiarze kontaktów z władza, z cesarzem. Są odzwierciedleniem nowej sytuacji, w jakiej znaleźli się chrześcijanie i Kościół. Ponadto Ambroży jest pierwszym wielkim biskupem okresu pokonstantyńskiego w Cesarstwie Zachodnim, który znalazł się w tej nowej sytuacji, także osobistej z powodu przejścia od pełnienia władzy cywilnej do religijnej*.

Skoro podstawowym celem listów Ambrożego było nie tyle ukazanie prawd wiary $\mathrm{i}$ ich tłumaczenie, jako że nie znajdujemy w epistolarium żadnego listu

${ }^{7}$ Ambrosius, De fide I 4, PL 16, 529: „Mallem quidem cohortandi ad fidem subire officium, quam de fide disceptandi; in altero enim religiosa confessio est, in altero incauta praesumptio; sed quoniam neque tu cohortatione indiges, neque ego excusandi liber, ubi pietatis officium est, audax negotium verecunda occasione suscipiam; ut de fide pauca disceptem, de testimoniis plura contexam”, thum. I. Bogaszewicz: Św. Ambroży z Mediolanu, O wierze, Warszawa 1970, 10.

8 J. Naumowicz, Wstęp, w: Św. Ambroży z Mediolanu. Listy, I, BOK 9, Kraków 1997, 13-14.

* Z uwagi na to, że prezentowany artykuł jest drugą częścią dyptyku na temat wiary w listach św. Ambrożego, niniejszy wstęp został powtórzony z opublikowanej już pierwszej części; por. Wysocki, ,Nie ma nic ważniejszego od religii, nic wznioślejszego od wiary”, s. 497-498. 
stricte dogmatycznego, a raczej zachęcanie do wiary, to powinny być one obfite w przykłady wiary, wzory ludzi, którzy praktykowali wiarę w codziennym życiu. I tak rzeczywiście jest. Biskup Ambroży wielokrotnie przytacza przykłady zarówno biblijne, jak i z codziennego ówczesnego życia, tych, których w wierze należy naśladować i którzy zachęcają na różne sposoby do wiary.

Pierwszorzędnymi wzorami wiary są dla Ambrożego postaci biblijne. Rozpoczynając od Starego Testamentu. postacią, którą przywołuje biskup w tym kontekście jest oczywiście ojciec wiary - Abraham. Ten wymiar - synostwo w wierze - Ambroży podkreśla szczególnie. Abraham uwierzył Bogu i przez to został uznany za sprawiedliwego, co oznaczało, że przeszedł on z niedowiarstwa do wiary i został usprawiedliwiony przez wiarę, a nie na podstawie uczynków Prawa. Mając dwóch synów - pierworodnego z niewolnicy i drugiego z wolnej - otrzymał polecenie, aby dziedzictwo przejął syn wolnej, co świadczy - według Ambrożego - że „bardziej synami Abrahama są ci, którzy są nimi przez wiarę, lepsi są bowiem dziedziczący przez wiarę od dziedziców z urodzenia. Prawo jest wychowawca, wiara jest wolna"9. Szczególnym aktem wiary Abrahama była gotowość ofiarowania syna. Według biskupa Mediolanu Abraham został pochwalony i otrzymał wielkie wynagrodzenie, a więc liczne potomstwo w wierze, ,gdyż uwierzył, że na rozkaz Boży mogło stać się pobożnym aktem nawet zabicie kogoś z najbliższej rodziny" ${ }^{10}$. Oczywiście Ambroży nie pochwala i nie zachęca do zabijania członków rodziny, lecz podkreśla siłę i ogrom wiary Abrahama. Dlatego w jednym z listów podkreślał:

„[Abraham] jednak, gdy otrzymał rozkaz powstrzymania się od ofiary z syna, chętnie odłożył miecz; i ten, który ze względu na swoją wiarę spieszył się z ofiarowaniem jedynego syna, z większym zapałem pobożności pospieszył, aby zamiast niego złożyć owcę w ofierze"l1.

Wiara Abrahama wyraża się w gotowości do największych poświęceń, ale jeszcze bardziej w gotowości słuchania Boga i otwartości na Jego polecenia. Wiara Abrahama bowiem, a co za tym idzie także każdego człowieka, zakłada wiarę do końca, we wszystko, nie częściowo. Taka wiara doprowadziła ostatecznie Abrahama do największej miłości - miłości Boga ${ }^{12}$.

\footnotetext{
${ }^{9}$ Ambrosius, Epistula 66, 1, ed. G. Banterle, SAEMO 20, Milano - Roma 1988, 184: „Unde colligitur quod hi magis Abrahae filii qui ex fide; praestant enim fidei quam generationis heredes. Lex paedagogus est, fides libera”, thum. P. Nowak: Św. Ambroży z Mediolanu. Listy, II, BOK 22, Kraków 2003, 125.

${ }^{10}$ Tenże, Epistula 27, 14, ed. G. Banterle, SAEMO 19, Milano - Roma 1988, 258: „Poterat turpe arbitrari, quod imperabat deus? Sarra quia risit, incredulitatis coarguta est, Abraham laudatus, quia in verbo dei non haesitavit, et donatus remuneratione maxima, quia iubente deo pie posse fieri credidit etiam parricidium", BOK 9, 201.

${ }^{11}$ Tenże, Epistula 35, 6, SAEMO 19, 330: „Tamen ubi abstinere a filio iussus est, gladium libenter recondit, et qui immolare unigenitum fidei intentione properabat, maiore pietatis studio festinavit ovem subrogare sacrificio", BOK 9, 252.

${ }^{12}$ Por. tenże, Epistula 66, 5.
} 
W Nowym Testamencie dziećmi Abrahama i wzorami wiary są według Ambrożego przede wszystkim apostołowie ${ }^{13}$, ale także inni, którzy przyjęli Chrystusa i głosili Go ${ }^{14}$. Spośród nich biskup Mediolanu wyróżnia przede wszystkim św. Pawła ${ }^{15}$. On dzięki temu, że prowadził życie wiary, był obecny przy Panu i jednocześnie pozostając na ziemi doświadczał rzeczywistości niebieskiej ${ }^{16}$. Wiara prowadzi więc do kontemplacji, do przebywania mistycznego z Bogiem. Na przykładzie Pawła - według Ambrożego - widać, że wiara pełni także rolę swoistego surowego sędziego, który w pokorze pozwala osądzić swoje życie i swoją wiarę. Pozwala stanowczo trwać przy Bogu, nawet pomimo trudności ${ }^{17}$.

Jednak nie tylko w odległej przeszłości, na kartach Pisma Świętego, można znaleźć - według biskupa Mediolanu - przykłady i wzory wiary. Również świat współczesny Ambrożemu obfitował w takie osobowości. W walce $\mathrm{z}$ herezjami Ambroży wskazywał na przykład Atanazego, „który był jakby filarem wiary (quasi columen fidei fuit)" ${ }^{\prime 18}$. Pisząc do wiernych w Vercelli, skłóconych po śmierci biskupa i stojących wobec wyboru nowego pasterza, Ambroży wskazuje na przykład wiary biskupa Euzebiusza, który „ze względu na wiarę wolał i wybrał również twardy los wygnania, przyłączywszy się do świętej pamięci Dionizego"19. Ze względu na wiarę, która nie zlękła się prześladowań i została zachowana $\mathrm{w}$ cierpieniach, powinni być oni zachowani przez wiernych $\mathrm{w}$ pamięci. Euzebiusz tym bardziej jest wzorem wiary, że „wzniósł jako pierwszy sztandar wyznania wiary" 20 . Są więc oni wzorem wytrwałości w wierze nawet w obliczu prześladowań i wygnania. Ma to oczywiście swój szczególny wydźwięk wobec licznych przypadków wygnania ortodoksyjnych biskupów oraz prześladowań wiernych ze strony frakcji ariańskiej. Choć nie było zagrożenia prześladowaniami ze strony pogan, to jednak Ambroży - właśnie w kontekście sporów ariańskich - przywoływał postaci nie tylko tych wiernych, którzy udali się na wygnanie, ale także tych, którzy ponieśli śmierć męczeńską.

Męczennicy byli dla biskupa Mediolanu świadkami i wzorami wiary, ale przede wszystkim byli świadkami prawdziwej, ortodoksyjnej wiary, ,gdyż ich

\footnotetext{
${ }^{13}$ Por. tenże, Epistula 22, 10.

${ }^{14}$ Por. tamże.

${ }^{15}$ Por. W. Turek, Paolo maestro di vita spirituale nelle Lettere di Ambrogio, w: Atti del V Sim-
} posio di Tarso su S. Paolo Apostolo, ed. L. Padovese, Turchia: la Chiesa e la sua storia 12, Roma 1998, 269-279.

${ }^{16}$ Por. Ambrosius, Epistula 11, 13.

${ }^{17}$ Por. tenże, Epistula 14 [extra coll.], 73.

${ }^{18}$ Tenże, Epistula 8 [extra coll.], 7, ed. G. Banterle, SAEMO 21, Milano - Roma 1988, 216, thum. P. Nowak: Św. Ambroży z Mediolanu. Listy, III, BOK 28, Kraków 2012, 172.

${ }^{19}$ Tenże, Epistula 14 [extra coll.], 68, SAEMO 21, 298: „Pro fide quoque exilii dura praeoptavit atque elegit coniuncto sibi sanctae memoriae Dionysio qui posthabuit imperatoris amicitiam exilio voluntario", BOK 28, 231.

${ }^{20}$ Tamże 14 [extra coll.], 70, SAEMO 21, 298: „Eusebius sanctus prior levavit vexillum confessionis", BOK 28, 232. 
męka wszystkim przekazała prawdziwą znajomość wiary"21 jak mówił o odnalezionych męczennikach mediolańskich Protazym i Gerwazym. Prawdziwy męczennik nie może bowiem sprzeciwiać się prawdziwej wierze ${ }^{22}$. Wierni zaś, którzy gromadzili się wokół odnalezionych relikwii dowodzili według Ambrożego, że posiadają znajomość prawdziwej wiary ${ }^{23}$. Przeciwieństwem byli oczywiście arianie, którzy nie wierzyli w dziejące się cuda i uzdrowienia, czyli nie wierzyli Chrystusowi ${ }^{24}$. Ambroży tę niewiarę tłumaczy zazdrością, którą żywili arianie wobec dokonujących się znaków. Ich zazdrość była skierowana ku odnalezionym męczennikom, a ściślej ku ich prawdziwej wierze, która sprawiała cuda w imię Chrystusa, ponieważ:

„męczennicy mieli inną wiarę, niż ta ich [arian - M.W.] wiara. Bo inaczej by nie zazdrościli ich dziełom; to znaczy gdyby nie sądzili, że tamci mieli tę wiarę, której oni sami nie mają; tę wiarę, potwierdzoną tradycją przodków, której same demony nie mogą negować, lecz którą arianie negują"25.

Męczennicy posiadają zatem wiarę prawdziwą, potwierdzoną przez Tradycję, zdolną działać cuda. Posiadają wiarę umocnioną cierpieniem, bowiem „ból czyni wiarę bardziej wiarygodną; większa jest bowiem łaska wiary, jeżeli ktoś dla religii nic sobie nie robi z bólu" 26 .

Innym przykładem wiary był biskup Tesalonik Acholiusz, po którego śmierci Ambroży kieruje do wiernych i duchowieństwa list wychwalający zasługi zmarłego. Śmierć Acholiusza traktuje Ambroży jako pozbawienie ludu muru obronnego wiary (raptus est nobis murus fidei), który nie został sforsowany przez herezje barbarzyńców ${ }^{27}$, samego zaś Acholiusza przedstawia jako tego, który umacnia wiarę ludzi i niesie ją tam, gdzie jej brakuje. Z tego powodu został on wybrany biskupem w Macedonii, ,,aby tam, gdzie przedtem wiara kulała z powodu biskupa, następnie przez biskupa zostały umocnione fundamenty murów wiary"28. Warto przy tym zwrócić uwagę na swoisty antyprzykład i antywzór wiary w postaci anonimowego biskupa, który zaniedbywał

${ }^{21}$ Tenże, Epistula 77, 8, SAEMO 21, 158: ,[...] quorum passio veram fidei scientiam omnibus indicavit", BOK 28, 111.

${ }^{22}$ Por. tamże.

${ }^{23}$ Por. tamże 77, 15.

${ }^{24}$ Por. tamże 77, 19.

${ }^{25}$ Tamże 77, 20, SAEMO 21, 164-166: „Si martyribus - restat enim ut si mihi non invident martyribus invidere videantur - ostendunt alterius fidei fuisse martyres quam ipsi credunt. Neque enim aliter eorum operibus inviderent nisi fidem in his fuisse eam quam isti non habent iudicarent, fidem illam maiorum traditione firmatam, quam daemones ipsi negare non possunt sed Arriani negant", BOK 28, 116.

${ }^{26}$ Tenże, Epistula 69, 14, SAEMO 20, 210: „In tantum autem abest nocuisse fidei circumcisionis dolorem, ut probabiliorem fidem faciat dolor; maior enim fidei gratia, si quis pro religione contemnat dolorem, et hic magis habet praemium quam ille qui ideo dolorem voluit circumcisione subire, ut gloriaretur in lege et laudem ex hominibus magis quam ex deo quaereret", BOK 22, 140.

${ }^{27}$ Tenże, Epistula 51, 5, SAEMO 20, 86, BOK 22, 46.

${ }^{28}$ Tamże 51, 12, SAEMO 20, 90: „Ad summum sacerdotium a Macedonicis obsecratus populis, 
sprawy wiary i przez którego w Macedonii „wiara kulała”29, a jednocześnie na przykład wiary Acholiusza, który umacniał fundamenty wiary.

We współczesnym Ambrożemu świecie przykładami wiary dla wiernych są nie tylko konkretne osoby, ale także osoby pełniące określone funkcje w Kościele. W liście 16. do Ireneusza o królestwie Bożym Ambroży stwierdza:

„I dlatego najpierw ustanowił w Kościele - napełnionych swoim Duchem - jednych apostołami, innych prorokami, innych ewangelistami, innych pasterzami i nauczycielami, aby przez ich zachęty dokonywał się postęp wierzących i wzrastało dzieło wiernej posługi" ${ }^{30}$.

Zatem to ci ludzie powołani są w sposób szczególny do świadczenia o wierze i do rozwoju wiernych. Na pierwszym miejscu - bo wzmianek tych jest najwięcej - stawia Ambroży autorytet biskupów i ich posługiwanie wierze ${ }^{31}$. Oni w pierwszym rzędzie odpowiedzialni są za wiarę. To oni mają prawo i obowiązek dyskutować o prawdziwości wiary, o tym jak należy postępować bez szkody dla wiary ${ }^{32}$, choć muszą pamiętać, że sprawy te powinny być rozpatrywane w Kościele $\mathrm{w}$ obecności ludu ${ }^{33}$ i nie mogą uzależniać spraw wiary od władzy politycznej, gdyż to może prowadzić do błędu ${ }^{34}$. Biskupi muszą według Ambrożego przede wszystkim zachowywać prawdziwa, ortodoksyjną wiarę, muszą wypowiadać się jasno i precyzyjnie po stronie ortodoksji, wystrzegając się wszelkiego błędu i unikając popierania wszystkiego, co ma choćby pozór błędu, gdyż to może prowadzić do umocnienia się herezji i niewłaściwego wykorzystania słów biskupich do ataków na prawdziwą wiarę. Pisał o tym przy okazji sprawy biskupa Bonozusa:

„Jeżeli już od biskupów otrzymują takie autorytatywne poparcie i będzie się wydawać, iż Maryja wiele razy rodziła, to z tym większą gorliwością będą usiłowali zwalczać prawdę wiary"35.

Na biskupach spoczywa więc wielka odpowiedzialność i troska o sprawy ortodoksji, wiary i moralności. Dlatego też w liście do wiernych i duchowieństwa w Vercelli stojących w obliczu wyboru biskupa pisał o idealnym biskupie:

electus a sacerdotibus, ut ubi ante fides per sacerdotem claudebatur, ibi postea per sacerdotem muralia fundamenta fidei confirmarentur", BOK 22, 49.

${ }^{29}$ Tamże.

${ }^{30}$ Tenże, Epistula 16, 11, SAEMO 19, 166: „Ideo que primum repletos spiritu suo posuit in ecclesia apostolos, prophetas alios, alios evangelistas, alios autem pastores et doctores, ut eorum adhortationibus consummaretur profectus credentium et ministerii fidelis opus cresceret”, BOK 9, 135 .

${ }^{31}$ Por. M. Zelzer, Vescovi e pastori alla luce delle lettere ambrosiane, w: Vescovi e pastori in epoca teodosiana, II, SEA 58, Roma 1997, 559-568.

${ }^{32}$ Por. Ambrosius, Epistula 74, 27. Zob. tenże, Epistula 75, 15-16.

${ }^{33}$ Por. tenże, Epistula 75, 17.

${ }^{34}$ Por. tamże 75, 4.15.

${ }^{35}$ Tenże, Epistula 71, 3, SAEMO 21, 36: „Iam si hanc accipiant a sacerdotibus auctoritatem et videatur Maria partus fudisse plurimos, maiore studio veritatem fidei expugnare contendent”, BOK 28, 18. 
„Niech w nim będzie wiara i dojrzałość obyczajów: nie jedna bez drugiej, lecz obie cechy w jednej osobie powinny się zgadzać z dobrymi uczynkami i dziełami"’36.

Taka postawa może prowadzić do uspokojenia sytuacji kryzysowej, jak w przypadku Vercelli, ale także do nawrócenia pogan, którzy dzięki nauczaniu biskupa zaczynają wierzyć i przyjmują słowo Boże ${ }^{37}$. Czasami jednak postawa wiary i nauczania prawdziwej ortodoksyjnej wiary spotyka się z odrzuceniem, zdarza się, że „nie wierzy się nauczaniu biskupów”, wtedy powinni oni mieć świadomość, że głoszą prawdę, która przepowiadana była przez Chrystusa i przez napomnienia aniołów, która zawarta jest w apostolskim wyznaniu wiary, „które Kościół Rzymski strzeże i zachowuje zawsze nienaruszone”38.

Specyficzną grupą, której wiarę prezentuje biskup Ambroży, są władcy Imperium Rzymskiego ${ }^{39}$. Spośród zachowanych listów Ambrożego 14 skierowanych jest właśnie do cesarzy. W większości poruszają one tematy dotyczące bezpośrednio wiary jak np. listy napisane przy okazji sporu o bazyliki ${ }^{40} \mathrm{czy}$ reakcji pogańskiej ${ }^{41}$, albo kary za podpalenie synagogi ${ }^{42}$. Nawet jeżeli dotyczą spraw pozornie nie związanych z wiarą - jak np. kwestia mordu w Tesalonice ${ }^{43}$ - to jednak Ambroży odnosi je do wiary ${ }^{44}$. Trzeba pamiętać, że biskup Mediolanu koresponduje z panami życia i śmierci. Ma tego świadomość, bo przecież

${ }^{36}$ Tenże, Epistula 14 [extra coll.], 50, SAEMO 21, 288: „Sit in eo fides et morum maturitas, non alterum sine altero sed utrumque in uno cum bonis operibus conveniat et factis", BOK 28, 224.

${ }^{37}$ Por. tenże, Epistula 5, 7.

${ }^{38}$ Tenże, Epistula 15 [extra coll.], 5, SAEMO 21, 328: „Sed si doctrinis non creditur sacerdotum, credatur oraculis Christi, credatur monitis angelorum dicentium: Quia non est impossibile deo omne verbum, credatur symbolo apostolorum, quod ecclesia Romana intemeratum semper custodit et servat", BOK 28, 253.

${ }^{39} \mathrm{Na}$ temat obrazu chrześcijańskiego władcy w korespondencji Ambrożego zob. K. Gross-Albenhausen, ,Imperator christianissimus”: der christliche Kaiser bei Ambrosius und Johannes Chrysostomus, Stuttgart 1999; M. Wysocki, Obraz chrześcijańskiego władcy w listach św. Ambrożego, VoxP 34 (2014) t. 61, 173-180; M. Sordi, I rapporti di Ambrogio con gli imperatori del suo tempo, w: „Nec timeo mori”. Atti del Congresso internazionale di studi ambrosiani nel XVI centenario della morte di sant'Ambrogio (Milano, 4-11 Aprile 1997), ed. L.F. Pizzolato - M. Rizzi, Studia Patristica Mediolanensia 21, Milano 1998, 107-118. Ogólnie o listach Ambrożego skierowanych do Imperatorów i o relacji biskupa Mediolanu do cesarzy zob. R. Klein, Die Kaiserbriefe des Ambrosius. Zur Problematik ihrer Veröffentlichung, „Athenaeum” 58 (1980) 335-371.

${ }^{40}$ Por. Ambrosius, Epistula 75.

${ }^{41}$ Por. tenże, Epistula 72; 73. Zob. L. Cracco Ruggini, Ambrogio e le opposizioni anticattoliche fra il 383 e il 390, „Augustinianum” 14 (1974) 409-449; E. Dovere, Il vescovo ,teodosiano” quale riferimento per la normazione ,de fide” (secc. IV-V), w: Vescovi e pastori in epoca teodosiana, s. 161-184 (spec. s. 168-172, o Ambrożym i jego listach 72 i 75); L.F. Pizzolato, Ambrogio e la libertà religiosa nel IV secolo, w: Cristianesimo e istituzioni politiche. Da Costantino a Giustiniano, ed. E. dal Covolo - R. Uglione, Biblioteca di Scienze Religiose 134, Roma 1997, 143-155.

${ }^{42}$ Por. Ambrosius, Epistula 74.

${ }_{43}^{43}$ Por. tenże, Epistula 11 [extra coll.].

${ }^{44} \mathrm{O}$ szczególnej roli biskupa Ambrożego zob. R. Andrzejewski, Między Bogiem a cesarzem Ambroży z Mediolanu, AK 93 (1979) 64-72. 
pisze $\mathrm{w}$ jednym $\mathrm{z}$ listów, że gotowy jest udać się natychmiast na wygnanie, że spodziewa się tego, gdyż przeciwstawia się cesarzowi ${ }^{45}$. Adresaci listów traktowani są więc przez Ambrożego z należytym szacunkiem i jednocześnie - jeżeli tego wymaga dobro człowieka wierzącego i wiary - ze stanowczościa, a nawet surowością. Ambroży zdaje sobie sprawę, że odbiorcy jego listów są ludźmi „na świeczniku” i że od ich postępowania, ich stosunku do wiary i ich wiary zależy tak naprawdę wiara wielu ludzi, w tym przede wszystkim wiara ich następców i najbliższego otoczenia, od którego wielokroć zależy los wierzących i wiary. Dlatego stosuje w swych listach retoryczne zabiegi, niejednokrotnie hiperbole, mówiąc o wierze imperatorów. Na przykład w liście skierowanym do cesarza Walentyniana w sprawie próby przywrócenia kultów pogańskich w Cesarstwie Rzymskim, w odpowiedzi na relację prefekta Symmacha, Ambroży asekuracyjnie pisze:

„Przeto - nie dlatego, jakobym wattpił o twojej wierze, lecz [chcąc być] przewidujący w ostrożności i pewny sumiennego zbadania sprawy - tym pismem odpowiadam na stwierdzenia relacji, prosząc tylko o to, byś nie zwracał uwagi na elegancję wymowy, lecz na [przekonywująca] moc faktów"46.

Cesarz, który posiada prawdziwą, ortodoksyjną wiarę nie może zatem wystapić przeciwko niej i stanąć po stronie pogan, którzy nie mogą wykazać się wiara, a jedynie elegancją wymowy.

Podobne dowartościowanie wiary cesarskiej w obliczu wydarzeń, które mogły mieć wpływ na życie Kościoła i samego Ambrożego, można odnaleźć w liście z września 394 r. do cesarza Teodozjusza, po jego zwycięstwie nad uzurpatorem Eugeniuszem. Według biskupa Mediolanu zwycięstwo to było darem i odpowiedzią Boga na wiarę i pobożność cesarza, przy którym - niczym w zdarzeniach Starego Testamentu - walczył sam Bóg, który w ten sposób przywrócił postać dawnej religijności ${ }^{47}$. Wyrażając zaś w liście do cesarza Teodozjusza smutek i ból po śmierci Walentyniana II biskup Mediolanu podkreślał, że został on ukształtowany przez wiarę i pouczenia Teodozjusza, przez co osiagnął wielką pobożność i zmienił swoje nastawienie do Ambrożego, stając się z prześladowcy jego przyjacielem ${ }^{48}$. Po synodzie w Akwilei Ambroży pisał zaś do tego samego cesarza o zbawiennym wpływie jego wiary na biskupów zgromadzonych na synodzie:

${ }^{45}$ Por. Ambrosius, Epistula 76, 10; zob. też Epistula 75, 18; 76, 8.

${ }^{46}$ Tenże, Epistula 73, 2, SAEMO 21, 62: „Itaque non fidei tuae ambiguus sed providus cautionis et pii certus examinis hoc sermone relationis assertioni respondeo, hoc unum petens ut non verborum elegantiam sed vim rerum expectandam putes", BOK 28, 38.

${ }^{47}$ Por. tenże, Epistula 2 [extra coll.], 3. Warto zauważyć, że w ten sposób Ambroży nawiązuje do religio vetus, do wielokrotnie w dziejach Rzymu podkreślanej tradycji i mores maiorum. Oczywiście nie jest to powrót do religii pogańskiej, ale do religijności i oddania Rzymian bogom, a w tym przypadku Bogu chrześcijan.

${ }^{48}$ Por. tenże, Epistula 25, 2-3. 
„Znajomość twojej wiary rozprzestrzeniona po całym świecie uspokoiła głębokie uczucia naszego ducha"49.

W okoliczności zaś niezwykle trudnej, jaką była rzeź w Tesalonice, biskup Mediolanu, napominając cesarza Teodozjusza, jednocześnie wskazuje, co w obliczu niepokoju wywołanego masakrą, może dać bezpieczeństwo wiary i spokój Kościołowi. Ambroży pisze, że sprzyja im to „gdy cesarze będa chrześcijańscy i pobożni”50. Zatem to wiara cesarza może uratować pokój, uśmierzyć zamieszki i zachować Kościół w pokoju. Od wiary imperatorów zależy więc bardzo wiele, nawet jeżeli takie słowa są tylko ambrozjańskimi captatio benevolentiae i licentia poetica.

Ambroży - oprócz wskazywania bezpośrednio na zależność powodzenia i wykonanie pewnych czynności od wiary cesarza - wielokrotnie pisał również o wierze imperatorów, przede wszystkim oczywiście chcąc uzyskać coś dla Kościoła i dla siebie. Był w tym politycznie doskonały. Ambroży świetnie bowiem wiedział jak ,podejść" cesarzy - podobne zabiegi retoryczne stosował w mowach pogrzebowych, które miały na celu zapewnienie Ambrożemu przychylności następców zmarłych i ich najbliższego otoczenia ${ }^{51}$. W liście 73. w odpowiedzi na relację Symmacha Ambroży wychwalał na przykład wiarę młodego cesarza Walentyniana, zestawiając jego młody wiek z dojrzałością i mocą jego wiary, określając go jako weterana w sprawach wiary (fidei tamen virtute veteranus $)^{52}$. A tymczasem $\mathrm{w}$ liście do tegoż cesarza $\mathrm{w}$ obronie katolickich kościołów w Mediolanie Ambroży określa imperatora jako stanowczego w wyznawaniu wiary ${ }^{53}$, ale jednocześnie przypomina mu, że dopiero musi zasłużyć na chrzest i że uzurpuje sobie decyzje dotyczące wiary, choć jeszcze nie

${ }^{49}$ Tenże, Epistula 8 [extra coll.], 1, SAEMO 21, 214: „Fidei tuae diffusa toto orbe cognitio intimum nostrae mentis demulsit affectum", BOK 28, 170.

${ }^{50}$ Tenże, Epistula 11 [extra coll.], 14, SAEMO 21, 238: ,ut perturbationes auferat, pacem vobis imperantibus servet, fides ecclesiae et tranquillitas perseveret, cui prodest Christianos et pios esse imperatores", BOK 28, 188.

${ }^{51} \mathrm{~W}$ taki sposób na przykład postapił w mowie pogrzebowej na cześć cesarza Teodozjusza. Wobec młodocianych następców tronu ukazywał zmarłego cesarza jako pełnego cnót, wierzącego, troszczącego się o Kościół, a pomijał zupełnie choćby kwestię rzezi w Tesalonice, choć wspominał pokutę, którą odbył Teodozjusz. W ten sposób ukazywał następcom Teodozjusza drogę, którą powinni podążać, a jednocześnie zaskarbiał sobie ich życzliwość, por. Ambrosius, De obitu Theodosii 6-8. 13. 15 i 34; H. von Campenhausen, Ambrosius von Mailand als Kirchenpolitiker, Berlin 1929; M. Wysocki, Idee eschatologiczne w mowach żatobnych św. Ambrożego, TPatr 7 (2010) 83-104; F.E. Consolino, „L'optimus princeps” secondo S. Ambrogio. Virtu imperatorie e virtu cristiane nelle orazioni funebri per Valentiniano e Teodosio, „Rivista storica italiana” 96 (1984) 1025-1045; taż, Teodosio e il ruolo del principe cristiano dal „De obitu” di Ambrogio alle storie ecclesiastiche, „Critica storica”15 (1994) 257-272; A. Paredi, Ambrogio, Graziano, Teodosio, „Antichità Altoadriatiche" 22 (1982) 17-49; F.J. Lomas, Teodosio parasigma de principe cristiano: consideraciones de Ambrosio, Rufino de Aquileya y Augustin sobre la imperial persona, „Storia historica historia antigua" 8 (1990) 149-165.

${ }^{52}$ Ambrosius, Epistula 73, 1, SAEMO 21, 62, BOK 28, 38.

${ }^{53}$ Por. tenże, Epistula 75, 3. 
poznał tajemnic tej wiary ${ }^{54}$. W odniesieniu do imperatora Teodozjusza, jak już zauważyliśmy, był Ambroży również zmienny w zależności od okoliczności, choć wiarę cesarza przedstawiał raczej w pozytywnym świetle. Nawet w obliczu konfliktu i groźby ukarania mnichów i biskupa w Callinicum w Syrii, Ambroży zwracał cesarzowi delikatnie uwagę, że ,ta tak wielka miłość, tak wielka wiara w Boga przez ten twój czyn zostanie zaciemniona"55. Po jego zwycięstwie nad Eugeniuszem, odpowiadając na prośbę cesarza o złożenie ofiary dziękczynnej za wynik bitwy, Ambroży przychyla się do tej prośby, która jest wyrazem ,wielkiej pobożności i wiary” imperatora ${ }^{56}$. Po synodzie w Akwilei, w związku z obsadą stolic biskupich, biskup Mediolanu wraz z innymi biskupami z uznaniem pisze, że cesarski ,święty duch jest oddany wszechmogącemu Bogu przez czystą i szczera wiarę" ${ }^{57}$. Gdy nadeszły wydarzenia w Tesalonice, jak już to wcześniej zauważono, odniesienie Ambrożego do Teodozjusza zmieniło się nieco. W liście do cesarza wprawdzie pochwalał jego wiarę, ale jednocześnie delikatnie wskazywał na pewne nieprawidłowości:

„Nie mogę zaprzeczyć, że masz gorliwość o wiarę; muszę przyznać, że masz bojaźń Bożą; lecz masz gwaltowne usposobienie: jeżeli ktoś stara się je uśmierzyć, szybko zwrócisz je ku miłosierdziu; jeżeli ktoś je drażni, coraz bardziej je pobudzasz, tak iż z trudem potrafisz je pohamować" 58 .

Wobec cesarza Gracjana nasz autor żywił szczególną sympatię i uznanie dla jego wiary ${ }^{59}$. To przecież na jego prośbę napisał dzieło De fide $e^{60}$. W jedynym

${ }^{54}$ Por. tamże $75,5$.

${ }^{55}$ Tenże, Epistula 74, 32, SAEMO 21, 104: „Haec tanta pietas, tanta erga deum fides hoc facto obfuscabitur", BOK 28, 70.

${ }^{56}$ Tenże, Epistula 2 [extra coll.], 4, SAEMO 21, 190: „Certum est placitam deo esse hostiam quae vestro offertur nomine, et hoc quantae devotionis et fidei est!”, BOK 28, 151.

${ }^{57}$ Tenże, Epistula 9 [extra coll.], 1, SAEMO 21, 218: „Sanctum animum tuum deo omnipotenti pura et sincera fide deditum sciebamus", BOK 28, 173.

${ }^{58}$ Tenże, Epistula 11 [extra coll.], 4, SAEMO 21, 234: „Quod habeas fidei studium non possum negare, quod dei timorem non diffiteor; sed habes naturae impetum, quem si quis lenire velit cito vertes ad misericordiam, si quis stimulet in maius exsuscitas ut eum revocare vix possis", BOK 28, 184.

${ }^{59} \mathrm{Na}$ temat relacji Ambrożego do cesarza Gracjana zob. J.R. Palanque, Un épisode des rapports entre Gratien et saint Ambroise. À propos de la lettre I de saint Ambroise, REA 30 (1928) 291-301; G. Gottlieb, Ambrosius von Mailand und Kaiser Gratian, Hypomnemata. Untersuchungen zur Antike und zu ihrem Nachleben 40, Göttingen 1973; T.D. Barnes, Ambrose and Gratian, „Antiquité Tardive" 7 (1999) 165-174; Y.M. Duval, Les Lettres d'Ambroise de Milan aux empereurs. Les échanges avec Gratien, w: Correspondances. Documents pour l'histoire de l'Antiquité tardive (Actes du colloque international, Lille, 20-22 novembre 2003), ed. R. Delmaire - J. Desmulliez P. L. Gatier, Collection de la Maison de l'Orient 40, Lyon 2009, 199-226.

${ }^{60}$ Por. Gottlieb, Ambrosius von Mainland und Kaiser Gratian, s. 26-87. Zdaniem niektórych badaczy (P. Nautin, Les premières relations d'Ambroise avec l'empereur Gratien. Le „De fide” (Livres I et II), w: Ambroise de Milan. XVI Centenaire, ed. Y.M. Duval, Paris 1974, 229-244) Gracjan poprosił Ambrożego o napisanie dzieła De fide, ponieważ chciał się zorientować w poglądach biskupa Mediolanu, którego jeszcze nie znał. 
zachowanym prywatnym liście do tego cesarza Ambroży daje wyraz swojego stosunku do imperatora i jego wiary. Już adres listu wydaje się wyjątkowy: „Biskup Ambroży do najszczęśliwszego cesarza i najbardziej chrześcijańskiego władcy Gracjana (Beatissimo Augusto Gratiano et Christianissimo principi Ambrosius episcopus)". W samej zaś treści listu również umieszcza pochwały doskonałej wiary i pobożności imperatora. Ambroży, ukazując swoją relację do cesarza, pisze:

„nasz Sędzia, którego ty wyznajesz i w którego pobożnie wierzysz, sam wie, że moje serce pokrzepia się twoją wiara, twoim zbawieniem, twoją chwała, i że ja zanoszę [za ciebie] należne modlitwy nie tylko z powodu publicznego obowiązku, lecz także z osobistej miłości. Przywróciłeś mi bowiem spokój Kościoła, zamknąłeś usta, i oby także serca, [ludzi] przewrotnych; a uczyniłeś to z autorytetem wiary nie mniejszym niż [autorytet twojej] władzy"61.

Zatem wychwala wiarę cesarza post factum działań porządkujących życie społeczne i religijne w kraju. Nieco dalej Ambroży sam wyraźnie przyznaje, że wprawdzie chwali cesarza, ale bardziej pochwala pokorę cesarza, a jeszcze więcej wiarę, która według słów władcy przywołanych przez biskupa, pochodzi od Chrystusa, którego bóstwa imperator nie neguje - co jest ważne przy okazji trwających sporów ariańskich ${ }^{62}$.

Ambroży jednak nie tylko mówił o doskonałej wierze żyjących imperatorów, ale także w jednym $\mathrm{z}$ listów zastosował ciekawy zabieg retoryczny polegający na ukazaniu doskonałości wiary zmarłego cesarza Walentyniana I, który przemawia do swego syna wskazując na prawdziwą wiarę w Boga jako siłę jego panowania i środek do utrzymania władzy ${ }^{63}$.

Powyższe słowa skierowane do imperatorów o ich wierze były niekiedy wypowiadane na wyrost. Ambroży wskazywał, zachęcał - zgodnie ze swym słowami z De fide - do wiary, ukazywał jej doskonałość i kierunek rozwoju. Nie mógł wszak powiedzieć, że cesarskiej wierze czegoś brakuje, że jest niedoskonała, ukazanie jej jednak na wyrost mogło prowadzić do zastanowienia i chęci osiagnnięcia takiej właśnie doskonałości w wierze. Tym bardziej, że stawiał Ambroży w swoich listach wobec cesarzy także wymagania dotyczące wiary. W liście do cesarza Walentyniana w sprawie przywrócenia kultów pogańskich zachęca młodego imperatora, aby sprawę przedstawił „zaprawionemu" w wierze cesarzowi Teodozjuszowi, bo jest to sprawa najwyższej wagi, „a nie ma nic ważniejszego od religii, nic wznioślejszego od wiary” ${ }^{\prime}$. W tym

${ }^{61}$ Ambrosius, Epistula 12 [extra coll.], 2, SAEMO 21, 242: „Scit ipse nostri arbiter, quem fateris et in quem pie credis, refici viscera mea tua fide, tua salute, tua gloria me que non solum officio publico debitas pendere preces sed etiam amore privato. Reddidisti enim mihi quietem ecclesiae, perfidorum ora atque utinam et corda clausisti; et hoc non minore fidei quam potestatis auctoritate fecisti”, BOK 28, 191.

${ }^{62}$ Por. tamże 12 [extra coll.], 4.

${ }^{63}$ Por. tenże, Epistula 72, 16.

${ }^{64}$ Tamże 72, 12, SAEMO 21, 44: „Nihil maius est religione, nihil sublimius fide”, BOK 28, 26. 
samym liście przypomina cesarzowi, że ,jak wszyscy ludzie, którzy są pod panowaniem rzymskim, służą wam, cesarzom i władcom świata, tak samo wy służycie wszechmocnemu Bogu i świętej wierze" ${ }^{65}$. W liście zaś 73. skierowanym do tegoż samego cesarza w odpowiedzi na argumenty przedstawione przez prefekta Rzymu Symmacha, biskup Mediolanu ostrzega przed przyjęciem urzędowym kultów pogańskich, gdyż od wiary zależy trwałość władzy i imperium ${ }^{66}$. W pierwszym liście w sprawie przywrócenia kultów pogańskich tytułuje Walentyniana „bardzo chrześcijańskim cesarzem (imperator Christianissime)" i jednocześnie przypomina mu jego rolę i zadania:

„[...] masz okazać swą wiarę w prawdziwego Boga, a także gorliwość o tę wiarę, roztropność i pobożność" ${ }^{67}$.

Jasno zatem Ambroży ukazuje, czego wymaga prawdziwa wiara i co jest zadaniem cesarza jako chrześcijańskiego władcy. Cesarz jest nie tylko przywódcą i wodzem, ale przede wszystkim ojcem w wierze, który swym poddanym ma ukazywać prawdziwą wiarę i chrześcijańską postawę.

Na podstawie powyższych analiz można stwierdzić, że święty Ambroży przedstawił w swych listach grono ludzi, których zadaniem jest ukazywanie i przekazywanie wiary. Bez wattpienia do dawania świadectwa wiary zobowiązani są wszyscy wierzący, jednak biskup Mediolanu ukazuje w swych listach grupy wiernych w sposób szczególny odpowiedzialnych za przekaz wiary, którzy mają być dla chrześcijan modelami wiary. Wskazuje zatem - zgodnie z chrześcijańskim toposem - w swych listach na postaci biblijne jako pierwszorzędne przykłady wiary oraz na męczenników, ale znacznie więcej uwagi poświęca współczesnym sobie biskupom i władcom Imperium Rzymskiego, którzy - według Ambrożego - w sposób szczególny odpowiedzialni są za ukazywanie i przekazywanie wiary. W wierze, której mają być przykładem dla innych, najważniejsze jest - według biskupa Mediolanu - zachowanie jej ortodoksyjności, wytrwałość w wierze i oczywiście przestrzeganie zasad moralnych wypływających z wiary. To właśnie listy Ambrożego są dziełami, w których w sposób prosty i zwyczajny, a nie dogmatyczny, mówi on o codziennym życiu wiarą, w którym ważne jest posiadanie swoistych przewodników i modeli

${ }^{65}$ Tamże 72, 1, SAEMO 21, 38: „Cum omnes homines qui sub dicione Romana sunt vobis militent imperatoribus terrarum atque principibus, tum ipsi vos omnipotenti deo et sacrae fidei militatis", BOK 28, 21.

${ }^{66}$ Por. tenże, Epistula 73, 33.

${ }^{67}$ Tenże, Epistula 72, 3, SAEMO 21, 38: „Ergo cum a te, imperator Christianissime, fides deo vero sit exhibenda, cum ipsius fidei studium cautio atque devotio, miror quomodo aliquibus in spem venerit, quod debeas aras diis gentium tuo instaurare praecepto, ad usus quoque sacrificiorum profanorum praebere sumptum", BOK 28, 22. 
wiary. Szereg takich postaci, ważnych dla ludzi IV w., ale również XXI w., prezentuje właśnie biskup Mediolanu w swoim epistolarium.

"WE ARE THE INTERPRETERS OF THE FAITH" (EPISTULA 10 [EXTRA COLL.], 8). THE FAITH AND THOSE WHO HAND IT DOWN PRESENTED IN ST. AMBROSE'S LETTERS

\section{(Summary)}

Presented paper is a part of the cycle of the articles on the faith in St Ambrose's letters. The second one - presented here - shows interpreters of the faith and those who in the special way are the examples and models of the faith and are responsible for the handing faith down to fellow Christians and to unbelievers. Without a doubt, all believers are obliged to bear witness to the faith, but the bishop of Milan shows in his letters the special groups of the faithful who are in a particular way responsible for the transmission of the faith and must be the models of faith. First of all Ambrose in his letters shows - according to the christian topos - the persons from the Bible and the martyrs as the spacial examples of faith. However, much more attention he pays to contemporary bishops and emperors of the Roman Empire who, according to Ambrose, in a special way are responsible for highlighting and giving an example of faith. In being an example of the Christian faith to others, the most important thing - according to Bishop of Milan - is persisting in its orthodoxy, perseverance in it, and of course observance the moral principles arising from the faith.

Key words: Ambrose, letters, faith, model of faith, example of faith.

Słowa kluczowe: Ambroży, listy, wiara, model wiary, przykład wiary. 
